pulsants are brought into play, that micturition takes place. When, however, the stimulus is more powerful, or the irritability of the bladder is increased, the purely reflex action of the involuntary muscles may be sufficient to overcome that of the constrictors of the neck of the bladder, and the inherent irritability of the canal, although, in most cases, the irritation of the struggle is sufficient to arouse the patient to consciousness and opposition to the act. This mixed muscular power is also evidenced when mictmition becomes irresistible, even in the waking state, through the action of the reflex spinal circle upon the expulsants.

"Such being the case, our object, in treating this unpleasant affection, should be,-to correct the deranged state of the general health, or so to act upon the spinal cord and nerves proceeding from it to the bladder and surrounding parts, as to adjust that "reflex circle;" to institute or restore a proper balance between the irritability of the mucous coat of the bladder and its contents; or, where this may not be possible, to bring the patient into that state when the stimulus of threatened micturition may be sufficient always to rouse him to conscionsness, or to render his sleep normally light, according to the special nature of the case.

"The meaus in general use in these cases will be found to act in one of these modes. The general invigorating means resorted to; act in restoring the normal reflex action of the spinal system, and rendering the sleep natural-opiates, tincture of muriate of iron, ura ursi, copaiba, acids, and alkakies, (as the case may be, mucilaginous articles, \&c., act in re.establishing the proper balance between the irritability of the mucous coat of the bladder and its contents; while irritating substances, as the tincture of lytta, \&c., act by specially and directly irritating the mucous membrane at the neck of the bladder, and the constricting muscles surrounding it. Blisters on the sacrum, again, while in some degree they act as tincture of the $f y$, by absorption, or by leeping the patient on his back while asleep, and lessening the irritation of the trigone from the contact of the urine, render also the sleep so light that the stimulus of threatened micturition is sufficient to arouse to consciousness. Mental affections act powerfully in this manner also. Shame and fear of punishment are the means at command for this purpose, and they are generally found of great service, althongh requiring great discrimination in their employment. The effect of anxiety of mind in rendering the sleep light and easily disturbed, must be familiar to all. MIany persons can invariably trust to awaking at any particular hour of the night they might strongly fix their mind upon before going to bed. Paralysis of the bladder is a complaint distinct from that under consideration, and so seldom likely to become a complication, that I do not consider it necessary to allude to the employment of strychnia. In these cases so much depends upon habit, that if we can succeed, through any of these neans, in checking the practice for but a short time, we may calculate on overcoming the tendency entirely.

"Guided by these principles, I hare succeeded in curing some of the most inveterate 'bed-wetters,' that I am sure would have foiled me had I not had the benefit of this thread of physiology to guide me through the labyrinth, and help me to retrace my steps when I occasionally made a wrong move."

\section{On Belladonna as a Remedy in Scarlatina.}

By W. M. FaIr brotrener, Esq., M.R.C.S., Southwark. Mr. Fatrbrother remarks that -

"Our correspondent who seems anxious that a good case should be made out for the virtues of belladonna in scarlatina, (THe LaNCET, June 24th, need only become a believer in homœopathy, and the difficulties are removed. As it is agreed that this drug in full doses produces constriction of the fauces, dryness of the thrca ${ }^{2}$, and impeded deglutition,(similia similibus curantar? - if it could ever be employed with advantage in scarlatina, it would be in the place of opium-a doubtful remedy - to relieve the restlessriess; but as its influence on the iris may have led some persons to believe that it exerts the same power over muscular action wherever applied, there would in such a case be some grounds for admitting its utility in relieving the spasm of the constrictors of the pharynx. Although first proposed as a remedy in roseola, it has been more employed as a prophylactic, in the long list of which, few, if any, are entitled to confidence.

"To relieve the distressing difficulty of swallowing, and the congested state of the mucous membrane of the fauces and pharynx, in scarlatina, ice swallowed slowly, and applied externally-due care being taken to keep up the temperature of the body-as recommended by Dr. Guy, has been very successful in my practice."
Cholera, and the Question of its Contagion.

A SUBSCRIBER who has read with interest the reports in TuE Lancet (pp. 341 and 451) of the discussion at the Westminster Medical society on the contagiousness of cholera, mentions one or two facts which occurred in a town in the north of Scotland in 1832, when the cholera was so prevalent. The population was about 2000 . The cholera gradually spread northwards; the authorities and inhabitants became alarmed; houses were whitewashed; disinfecting agents were fireely used, and patrols were stationed at all the ruads and bye-ways, so as to prevent the ingress of all persons from the infected districts. The cholera raged fiercely on almost all sides. Many of the victims were known to have been seized suddenly in the open air, and death often took place in a few hours. In one small fishing village, about five miles from the town, out of a population of 300 , it was reckoned that about onehalf of the inhabitants were carried off by this scourge. Yet, in the town itself, not one case occurred. This would go to prove the contagiousness of cholera.

On the other hand, one of the surgeons of the town attended daily in the infected districts, and was in close attendance upon the sufferers, yet he himself escaped, nor did he carry the infection to others. This fact would go, on the other hand, to prove the non-contagion of the disease. Our communicant adds-"I may state that $I$ am myself of opinion that the cholera is non-contagious."

\section{On Popular Prejudice against Traccination.}

By S. Gower, Esq., Surgeon, Hampstead.

VACCINATION, which has saved the lives of myriads, and spared the beauty and good looks of generations,--of, at least, two generations of our race,-is even still popularly denounced as an animal pestilence wantonly introduced among the human species, with evil results, if not for bad ends. Now, it is a fact that when small-pox pursued its career unmolested, not only were deaths incessant, but beauty in the female sex was in the headlong course of becoming quite a rarity. In saying this of vaccination, I do not speak of times which have entirely gone by. I know of cases in which the vaccination has been baffled by the mothers having scrubbed the arm with soap and hot water (as soon as the doctor was out of sight) so effectually as to have prevented its taking in three successive vaccinations. I know also of persons who, if a child of strumous habit has been vaccinated, will ascribe manifestaticns of disease occurring months and years afterwards to the effects of vaccine virus. It is an indiscretion which, even morally, and not politically speaking, is worse than a crime, for medical practitioners to countenance barricades erected by prejudice to obstruct the path of science.

\section{Thebirfms.}

A Practical Treatise on Variola Ovina, or Small-pox in sheep, \&.c. Illustrated with coloured plates. By JAMES B. Srmonds, Lecturer on Cattle Pathology in the Veterinary College. London: Churchill. 8vo, pp. 157.

Mr. Simonds, whose labours in the pathology of cattle are already so well known, both in his own profession and in ours, has done good service to veterinary medicine by the publication of hes present treatise. The occasion and the cause are thus expressed in the preface:- " . . . the sudden appearance of a malignant exanthematous disease in the flocks of several agriculturists in the vicinity of London." This exanthematous disease was found to possess many of the features of human variola, and was, in fact, the small-pox of sheep. Moreover, the disease manifested a disposition to spread widely among the flocks, and to become, in all probability, a permanent scourge.

"This ovine disorder," writes the author, "now bids fair to establish itself in England, and probably from time to time to breaik forth, and decimate our flocks, as variola does, or used to do, our population." And he further remarks,that " in Hamburgh Market a separate place is assigned to sheep that show any symptoms of contamination, or which are known to have come from a district where the disease exists."

Variola ovina, or, as it is called in France, clavalee, 